\title{
Informal Sector and the Economy in Sri Lanka: A Survey of Literature
}

\author{
S. M. P. SENANAYAKE \\ University of Colombo, Sri Lanka - smpsena@gmail.com \\ W. WIMALARATANA \\ University of Colombo, Sri Lanka -wimala@hotmail.com \\ S. P. PREMARATNE \\ University of Colombo, Sri Lanka - sppremaratne@yahoo.com
}

\begin{tabular}{|c|c|}
\hline $\mathbf{A R}$ & $\mathbf{T}$ \\
\hline $\begin{array}{l}\text { Article history: } \\
\text { Received: } \\
\text { Apr. 15. } 2015 \\
\text { Received in revised form: } \\
\text { Jun. } 4.2015 \\
\text { Accepted: } \\
\text { Jun. } 28.2015\end{array}$ & $\begin{array}{l}\text { It is customary to include all economic activities that are not } \\
\text { officially regulated as informal sector activities. The usual } \\
\text { definitions used to distinguish the informal sector from the formal } \\
\text { one appear to be problematic or fussy at their edges. This dichotomy } \\
\text { is not mutually exclusive as often thought but is in fact } \\
\text { interdependent in many respects. It is also argued that informal } \\
\text { enterprises often move upwards in a hierarchy of organizational } \\
\text { forms and finally end up as formal sector units through vertical } \\
\text { linkages. The informal sector provides jobs for very vulnerable low- } \\
\text { income groups in rural and urban sectors while contributing to the } \\
\text { GDP immensely in developing countries. This paper critically } \\
\text { examines the nature of the informal sector in Sri Lanka and studies } \\
\text { the links between the informal sector and its economy. The analysis } \\
\text { entirely employs secondary data and information. The findings of the } \\
\text { study demonstrate that the domestic (traditional) agriculture and } \\
\text { related activities in Sri Lanka are dominated by the informal sector, } \\
\text { which in turn is further strengthened by underworld activities. The } \\
\text { fear of tax burden, bribes, bureaucratic bungling, archaic rules and } \\
\text { regulations, and lack of dividends in formal activities drive many } \\
\text { people from the formal sector to the informal one. The informal } \\
\text { sector provides jobs and reduces unemployment and } \\
\text { underemployment, but in many cases the jobs are low paying and job } \\
\text { security is poor. It bolsters entrepreneurial activities, but at the } \\
\text { detriment of state regulations' compliance, particularly regarding tax } \\
\text { and labor regulations. }\end{array}$ \\
\hline
\end{tabular}




\section{Introduction}

It is a long-standing tradition to classify economies into groups such as developed and developing countries, north and south countries, first, second, and third world countries, industrialised and newly industrialised countries, etc. In addition to these popular international classifications, economies are internally classified as traditional and modern sectors, organized and unorganized sectors, urban and rural sectors, formal and informal sectors, and so forth. It seems that there are a number of alternative internal subdivisions within developing countries rather than within developed ones. As economic history suggests, many subdivisions of economies based on structural weaknesses disappear along with the process of economic development. An economy transforms gradually into a fully integrated single unit during the period of transition from developing to developed status.

It is customary to include all economic activities that are not officially regulated as informal sector activities. The International Labor Organization (ILO) introduced the concept of the informal sector nearly four decades ago. Accordingly, the informal sector consists of small-scale, self-employed activities (with or without hired workers), typically at a low level of organization and technology and with the primary objective of generating employment and incomes. The activities are usually conducted without proper recognition from the authorities, and escape the attention of the administrative machinery responsible for enforcing laws and regulations (Papola, 1980).

It is obvious that the informal sector is a distinctive feature in developing rather than developed countries, when all these characteristics are taken together and their contribution to GDP is significant (de Silva, 2013). Sri Lanka, as a developing country, provides classic examples about the functioning of the informal sector, hand in hand with the formal one in the economy. The informal activities are stronger in the rural sector, where the administrative mechanisms and the market forces are weaker compared to the urban and estate sectors of the economy.

The aim of this paper is to critically examine the nature of the informal sector in Sri Lanka. The paper further examines the links between the informal sector and the economy of Sri Lanka. The critical analysis is entirely based on secondary data and information. The article is structured in the following way: Section 2 presents the definitions and basic characteristics of the informal sector, and Section 3 discusses the size and diversity of the informal sector of Sri Lanka. Section 4 examines links 
between poverty and informal sector while Section 5 outlines links between agriculture sector and informal sector. Labor force and the informal sector are dealt with by Section 6, followed by Section 7, which concludes the paper.

\section{Definitions and characteristics of informal sector}

Research on activities encompassed by the term "informal sector" grew out of studies, in the fifties and sixties, on the dualistic nature of developing societies. The concept of dualism or a dual economy relates to various asymmetries in organization and production, and dualism in the structure of an economy such as between traditional and modern, and peasant and capitalist sectors was considered a distinguishing characteristic of developing countries. Development was seen in terms of a shift from a traditional to a modern, an unorganized to an organized, and a subsistence to a capitalist economy. Models of dualistic development recognized the interactions between the two sectors and examined their implications for growth. In this literature the pre-capitalist or traditional economy was expected to decline in relation to the growing capitalist or modern economy. In general, these models assumed a diminishing of the prevailing asymmetries over time and a slow disappearance of dualism in the course of development (Swaminathan, 1991).

Economists, as well as anthropologists, have seriously questioned the empirical validity of the dual economy paradigm when analyzing the informal sector. Indeed, the evidence is overwhelming: while formal and informal sector enterprises may be differentiated in terms of their capitalization, organization, labor processes, market penetration, and so on, it is generally the case that these differentiated enterprises are structurally articulated within a centralized political economy.

Therefore the usual definitions used to distinguish the informal sector from the formal one appear to be problematic or fussy at their edges. The problems are compounded when one is confronted with the task of classifying the rural households according to the accepted formal and informal dichotomy. It is now being suggested that this dichotomy is not mutually exclusive as often thought but is in fact interdependent in many respects. Some argue that informal enterprises often move upwards in a hierarchy of organizational forms and finally end up as formal sector units through vertical linkages. 
Linkages also exist in terms of products, markets, institutional environment, and technology with the other sectors of the economy. For instance, there could be production linkages between formal and informal sector enterprises in the form of subcontracts for producing certain component parts of a given product, and vertical linkages may be built up through input-output relationships. Market linkages exist when formal institutions, both public and private, buy the items produced by the informal sector for their own use. The institutional linkages stem from the use of banking, transportation, and insurance services, etc. by the informal sector enterprises. The technological linkage is facilitated through a downward transmission of technology and skills, to the informal sector units from those in the formal sector. Overall, the informal sector produces goods and services for the formal sector, and there are many linkages between the sectors (de Silva, 2013). Conversely, there may be other relationships among the informal, formal, and rural sector households. Many employees in the formal sector may seek to compliment their incomes by working part-time in some informal enterprises. The following characteristics are markedly present in the informal sector according to the ILO.

1. Entry and exit are easier than are in the formal sector. There are little or no official channels to pass through in the process, and entrepreneurs themselves decide what they want to do.

2. Informal sector enterprises usually employ fewer than ten workers, mostly immediate family members. They are paid in kind or money or both, mostly in an irregular manner and not entitled to pensions and other similar benefits. There are no age or gender restrictions; children, elders, and women work together.

3. The informal sector is heterogeneous: major activities are retail trade, transport, repair and maintenance, construction, personal and domestic services, traditional agriculture and related activities, traditional fishing and related activities, and manufacturing.

4. Capital investment is generally minimal, so work is mostly labor intensive, requiring low-level skills. Initial cost of investment and loss of winding up is, therefore, negligible.

5. Workers learn skills on the job rather than pre-job training; mostly such skills are acquired by children. 
6. The employer-employee relationship is often unwritten and informal, with little or no appreciation of industrial relations and workers' rights; the informal sector works in conjunction with, rather than in isolation from, the formal economy.

7. At present the informal sector is increasingly becoming integrated into the global economy.

\section{Informal sector (size and diversity) and the economy of Sri Lanka}

As was mentioned in Section I, the boundaries between the formal and informal sub-sectors in the urban sector cannot be properly demarcated due to the deficiencies in the definitions used. On the one hand, a household in the urban informal sector may be culturally and sociologically rural (Karunatilaka, 1981). On the other hand, the rural non-farm sector, which accounts for a substantial portion of the workforce of the rural population, operates within the same constraints experienced by their counterparts in the urban informal sector.

The data available in Sri Lanka at present are poor, at least to form an idea about the size and the diversity of the informal sector. The usual sub-classification of the economy into three sectors, namely urban, rural, and estate, in many surveys undertaken is not of much help in obtaining information on the size of the informal sector, nor do the GDP estimates of the country provide an estimate of the contributions made by the informal sector. However, the Department of Census and Statistics (DCS) in Sri Lanka conducted an industrial census in 2013 and is planning to estimate the informal sector's contribution. This is the Sri Lanka's first ever comprehensive economic census having been conducted on the informal sector by a government's data collection organization. The main objective of the census was to identify the informal sector and to estimate its contribution to the economy.

The literature on informal sector activities in Sri Lanka, which is capable of providing a detailed understanding of the sector, is scarce. There are some studies that basically focus on its overall picture. The pioneer contribution to the understanding of the informal sector was the study entitled "The Informal Sector of Colombo City," conducted by the Marga Institute in 1979. This work, based on a survey of the capital city, Colombo, made a significant contribution to the understanding of the informal activities and a conceptualization of informal enterprises of the urban areas of Sri Lanka. It identified the informal sector's magnitude and characteristics. The follow-up 
study of Marga Institute (1992) brought out characteristics of informal enterprises in three sectors, including the construction, motor repairs, and food services. This study is still unpublished. However, given the vast amount of studies undertaken in various disciplines with regard to formal economic activities which comprise only less than $50 \%$ of the total economic activities, almost half of the economic activities in the country seem to have been largely unexplained in Sri Lanka (Dayaratna-Banda, 2007). Sanderatne $(1989,1991,2004)$ in a series of papers has contributed to the understanding of the informal sector in Sri Lanka. Sanderatne (1989) presented a more formal analysis of the urban informal sector and also provided an overview of the rural and estate informal activities. Sanderatne (1991) gave a description of diverse activities of the informal sector with profiles of informal enterprises. Not only were the difficulties faced by the informal enterprises discussed but his paper also attempted to estimate the contribution of the informal activities to the GDP. In another paper Sanderatne (2002) examined the impact of globalization on the informal sector, concluding that globalization has positively contributed to its expansion. As Dayaratna-Banda (2007) remarked,

"These papers focus on the overall anatomy and characteristics of the informal sector in Sri Lanka. They do not include adequate micro-level data. Moreover, these papers do not specifically analyze informal trade sector in Sri Lanka."

The informal trade within the South Asian Region is another aspect discussed by some authors. Sri Lanka's informal trade with a few of the neighbouring countries was highlighted in a number of recent studies. Taneja et al (2002) estimated the size, characteristics, and reasons for informal foreign trade among the South Asian countries. The blame is basically pinned on various trade barriers for the presence of informal foreign trade. While Ghafur et al. (1990) highlighted illegal international trade in Bangladesh with a few neighboring countries, Karmacharya (2002) analyzed informal trade in the SAARC region assessing the size and the reasons for informal trade. However, the current understanding on informal foreign trade in Sri Lanka is not very clear; there is a lack of studies on domestic informal trade sector in Sri Lanka. Sanderatne (2002) analyzed the impact of globalization on informal sector and attempted to demonstrate the importance of Sri Lanka's informal commerce as basically explaining that globalization has positively contributed to developing the informal sector in Sri Lanka, especially informal trade. Still, its nature, extent, and characteristics have yet to be clearly known. Studying population age and the labor 
market in Sri Lanka, Vodopivec and Arunatilake (2008) opined that a majority of Sri Lankan old workers are engaged in the informal sector, work long hours, and are paid less than younger ones, which is the rigidity of the sector.

Hettige (1989) examined the interconnections between the urban informal economy and the political process, and from a sociologist's point of view discussed the implications of the expansion of the urban informal economy and the urban political process and the implications of the expansion of the urban informal economy for urban services and politics. Hettige $(1990,1986)$ also gave important sociological insights into the urban informal sector.

Therefore, the only survey available so far in Sri Lanka on the informal sector has restricted its coverage to the Colombo city and was carried out in 1976-1977. According to the data obtained in this survey, about $19 \%$ of the gainfully employed in the Colombo city belonged to the informal sector. The number thus employed was 34,400 , and the number of informal sector units of enterprises was 30,805 in 1979. The authors of the same study considered that this number was somewhat of an underestimate even then. These units comprised mainly of enterprises dealing with trade and commerce (57\%), services (22\%), manufacturing (12\%), and transport (8\%).

In the trade and commerce category most informal sector activists (70\%) were involved in the vegetables, fruits and fish trade, and the balance $30 \%$ in miscellaneous trading. More recent figures are not available as yet. The retail trade in vegetables, fruits, and fish in the city of Colombo is mostly in the hands of the informal sector although a few supermarket chains are also involved in such activities at present. Those miscellaneous trading activities include small informal enterprises and selfemployed traders, who operate from fixed locations or as itinerant vendors in a given locality. Such activities cover a wide range of commodities, such as textiles, garments, footwear, handbags, plastic goods, household utensils, and requisites. Likewise, the transport activities in the informal sector range from manual load carriers, hand carts and trollies, carts driven by oxen, and owner-driven taxis and trucks. The manufacturing and processing activities include small-scale manufacturing units and food processing units, whereas the service activities encompass enterprises dealing with tailoring, laundering, hair-dressing, and repair services of all types including motor vehicles and other items of equipment. Masonry, brick-laying, carpentry, steel and concrete work, electrical, colour-washing and painting, and drainage and water 
services are to be under construction. The cultivation and sale of leafy vegetables are classified as agricultural enterprises. Fishing enterprises mainly consist of sea fishing by operators. Apart from these legal occupations, there is an array of activities which can be classified as illegal and/or anti-social. These usually cover prostitution, drug peddling, and selling of illicit liquor. The Marga Institute's (1979) study has not included these illegal activities in their study.

If all these occupations are counted, then the size of the urban informal sector becomes even larger. The Marga Institute's study itself has taken note of the omission of certain important elements of informal sector activities which have grown in the environs of the city because its geographical coverage was confined to metropolitan limits. The formal furniture trading establishments in Colombo are closely linked with a wide network of small-scale wood working units in the south of Colombo, and the motor repair services in the suburbs form a significant component of the informal sector activities outside the city.

In addition, there are other types of informal sector activities (brokers in second hand markets, tuition classes, and tourist guides are some) which are not included in the Marga Institute's study. One such category is brokers who are involved in the second-hand market for vehicles and renting and selling of house and property. Tourist guides are another category which has been left-out therein. Though the Marga Institute's study has noticed the absence of mobile restaurants like those found in Singapore and Bangkok at the time of its survey, these units are now being established. However, data are still not available of the numbers involved. While manufacturing and processing accounted for a small percentage (12.4\%) of total number of informal sector enterprises within the Colombo city, a census undertaken by the Industrial Development Board of Sri Lanka in 1976 estimated that there was 15,599 "unapproved industrial units" in Sri Lanka. According to some tentative estimates, the contribution of the informal sector enterprises to manufacturing is about $44 \%$ of the values added and $67 \%$ of employment in the industrial sector in Sri Lanka (The World Bank Group, 1978; Athukorala, 1986). ILO/ARTEP has estimated the value added by such units at Rs. $507 \mathrm{~m}$, its share in manufacturing at $15 \%$, and the share in GDP at $2.1 \%$ in 1984 (ILO/ARTEP 1986). The value added by the informal sector enterprises involved in manufacturing alone works out to about Rs.4,909 in that year, and the estimated employment is about 14,286 persons. 
A study conducted by Gunatilake (2008) found that $66 \%$ of all employed people were working under informal work arrangements. While about $28 \%$ of total employment was made up of agricultural informal employment, non-agricultural informal employment accounted for $39 \%$ of total employment. About $50 \%$ of all informal workers are own-account workers, whereas $15 \%$ are family workers; only $29 \%$ are employees in informal enterprises or households. $45 \%$ of informal employees are in firms with less than five workers. The educated and skilled employees are less likely to be in informal employment.

Some unofficial results of the first ever economic census that was conducted by the DSC in Sri Lanka in 2013/2014 showed that about $62.5 \%$ of the business in the industry, trade, and services sectors are operated by only one person, and about $31.8 \%$ of businesses, functioned by between two to five persons. The initial findings of the census further revealed that $75.4 \%$ of the businesses are located in the rural areas while $24.6 \%$, in urban areas.

It becomes more difficult to discern the future trends of the informal sector activities due to lack of data. Casual observations suggested that the changes in economic policies that took place after 1977 provided increased opportunities for some branches of the informal sector. Trade is a notable example where pavement-hawking in textiles, plastic items, toys, etc. has increased. On the other hand, occupations connected with the tourist industry, the supply and manufacture of spare parts, and repairs to motor vehicles, machinery, and equipment, etc. must have declined due to various socio-economic reasons. Meanwhile, new types of activities have emerged. Three-wheeler taxis, selling of lottery tickets, mobile food trade using motor vehicles, and home-visited tuition are some of these new ventures. Thus, the composition of the activities in the informal sector appears to have changed with the changing socioeconomic conditions in the country, and hence have increased the diversity within the urban informal sector.

The number of rural non-farm enterprises which have so many parallels with the urban informal sector is much greater. Surprisingly, government census data are available regarding these occupations carried out in the rural sector, though similar data are not available on the urban informal sector because the difficulty in disaggregation is greater in respect of urban activities. Although it is difficult to disaggregate the figures into formal and informal enterprises, the numbers themselves 
speak of the size and magnitude of the non-agricultural occupations in rural areas. As the bulk of these is undertaken as self-employed and in family-type or cottage enterprises, they get qualified to be classed as rural informal sector. Senakaarachchi (1985) made mention of village level traders and boutique keepers. He also stated that the village-level government officials, teachers, clerks, mid-wives, etc. sometimes invest in cottage industries and similar income generating activities originating at the village level. He further observed that the relative importance of different occupations have undergone changes; the functional occupations in the rural areas which have been traditionally linked with caste and social obligations are disappearing under the pressures of social and economic change, but certain occupations which use nontraditional technology such as mechanics, welders, etc. and other occupations such as masons, carpenters, and drivers are expanding fast.

At the political independence Sri Lanka was a developing country; it is still a developing country after more than six decades of self-rule. It is estimated that the economy has recorded nearly $4 \%$ growth annually during this long period. The per capita nominal income was at USD120 in 1948, at the time of independence. This has reached to USD935 by 2003, pointing out that the per capita income have grown just over USD14 annually during this period. The per capita income was USD3,991 in 2013. Interestingly, although the per capita income is relatively low, Sri Lanka's survival indicators, literacy rates, and educational levels are high, even in comparison to some economically developed countries. This is mainly due to the high priority given to improve the living conditions of the general mass through a host of state sponsored subsidy programmes in the post-independent period. The successive consumer Finance and Socio Economic surveys conducted by the Central Bank of Sri Lanka have suggested that living conditions in Sri Lanka have improved over the time (Central Bank of Sri Lanka, 2003).

The overwhelming majority of the population is engaged in informal activities and their performances are directly affected not only by the current outcomes of the economy but also by the future prospects.

After a long period of self-rule Sri Lanka has inherited a fragile economy engulfed with a series of burning economic woes. Poverty, unemployment, inflation, balance of payments problems, government budget deficit, lack of proper socioeconomic infrastructure facilities, income inequality, bribery and corruption, and inefficiency in 
administration are a few of them. These problems should be taken into account in any overview of the economic situation in Sri Lanka. Not only the informal sector but also the formal sector has had to cope with these protracted problems and their consequences during most of the post independent period. The manner in which these problems are addressed will ultimately decide the sustainability of the long-term economic development of the country.

\section{Table 1}

Selected economic indicators

\begin{tabular}{|c|c|c|c|c|c|c|c|c|c|c|}
\hline Item & $\begin{array}{c}1951- \\
1955\end{array}$ & $\begin{array}{c}1956- \\
1960\end{array}$ & $\begin{array}{c}1961- \\
1965\end{array}$ & $\begin{array}{c}1966- \\
1970\end{array}$ & $\begin{array}{c}1971- \\
1977\end{array}$ & $\begin{array}{c}1978- \\
1988\end{array}$ & $\begin{array}{c}1989- \\
1993\end{array}$ & $\begin{array}{c}1994- \\
1997\end{array}$ & 2003 & 2013 \\
\hline $\begin{array}{l}\text { Population } \\
\text { change } \%\end{array}$ & 2.6 & 2.9 & 2.4 & 2.3 & 1.6 & 1.6 & 1.2 & 1.2 & 1.3 & 0.8 \\
\hline $\begin{array}{l}\text { Unemployment } \\
\text { rate }\end{array}$ & & & & & & & $\begin{array}{c}15.9 \\
(1990)\end{array}$ & $\begin{array}{c}12.9 \\
(1994)\end{array}$ & 8.4 & 4.4 \\
\hline GDP (real)\% & 1.6 & -0.2 & 1.2 & 2.9 & 1.3 & 3.3 & 3.6 & 3.9 & 5.9 & 7.3 \\
\hline Inflation change $\%$ & 0.7 & 0.6 & 1.7 & 4.2 & 5.7 & 12.7 & 8.9 & 10.4 & 6.3 & 6.9 \\
\hline $\begin{array}{l}\text { Budget, overall } \\
\text { balance } \% \text { of GDP }\end{array}$ & -2.1 & -4.5 & -6.0 & -6.8 & -8.2 & -13.8 & -9.9 & -8.3 & -8.0 & -5.9 \\
\hline $\begin{array}{l}\text { BOP, current } \\
\text { account balance } \% \\
\text { of GDP }\end{array}$ & 0.2 & -2.3 & -1.4 & -3.9 & -1.0 & -7.5 & -4.3 & -4.9 & -0.6 & -3.9 \\
\hline
\end{tabular}

Source: Central Bank of Sri Lanka

\section{Poverty and the informal sector}

Since the political independence, poverty has been the most challenging problem in Sri Lanka. Employment is the primary channel through which economic growth reduces poverty. When employment opportunities improve as economic activity expands, the benefits of growth will be broadly shared. However, access to employment is not sufficient. Currently, estimates from the ILO suggest that over 500 million employed individuals worldwide live in households that fall below the dollara-day poverty line; therefore, the quality of employment also matters. Informal employment represents a large share of total employment in many Asian countries. 
The household Income and Expenditure Surveys (2009) conducted in Sri Lanka suggested that poverty has declined over the past twenty years although it is still high in Sri Lanka. It is estimated that about $7 \%$ of the population are poor according to the lowest poverty line (one US dollar per day) and about $45 \%$ are poor according to the highest poverty line (two US dollars per day). The poverty in Sri Lanka is overwhelmingly a rural issue in which $31.3 \%$ of the people are poor; it is three times higher than the urban areas where poverty is estimated to be $8.6 \%$. In addition to the three decades of conflict, inadequate growth (especially low growth in agriculture), lack of opportunities and access to resources and markets, and isolation of the poor are the major causes for poverty. According to the survey results (DCS, 2009), the poverty in terms of HCI in urban sector is the lowest (6.7\%), and estate sector is the highest $(32.0 \%)$ while in rural sector it records $15.7 \%$. As Poverty Reduction Strategy Papers (PRSP) suggests, accelerating economic growth, improving productivity, and removing barriers are proper strategies to reduce poverty rather than the past strategy based on the concept of redistribution of income (Central Bank or Sri Lanka, 2003).

In dealing with the poverty-related issues, the informal sector is extremely important since it is almost synonymous with the rural sector, which dominates the poverty problem in Sri Lanka. Even in urban areas, poverty is mainly related to the informal sector. Except in a few skilled informal jobs, such as masonry and carpentry work, income is not growing in the informal sector to reduce the poverty levels in this sector.

\section{Agriculture and the informal sector}

The domestic agricultural sector (traditional agriculture) is the breeding ground for the overwhelming majority of informal sector employment in Sri Lanka. At the time of regaining political independence Sri Lanka was mainly an agricultural economy. The agriculture sector directly contributed nearly $40 \%$ of the national income in 1948 . The plantation sector dominated the agriculture while the domestic non-plantation agriculture was mainly a subsistence sector. More than half of the population were depended on agriculture. The contribution of the agriculture sector to the GNP has gradually declined over time and by 2013 this has gone down to $10.8 \%$.

Nearly $85 \%$ of the total population living in the rural areas in the late 1940 s were involved with agriculture and related activities, and this figure was about $77 \%$ in 2013. 
The main livelihood of the rural people was the paddy cultivation and other subsistence production related to small holder agriculture. This sector recorded a faster growth rate than the plantation agriculture during the post independence period while the subsistence nature of the sector was disappearing. The near self-sufficiency in rice was achieved in some years in the 1990s as a result of this rapid growth. About $77.3 \%$ of the population was still living in the rural sector by 2013. Rice cultivation and the related activities, such as fishing, other crop cultivation, livestock, and the cottage industries, are the major components of the domestic agricultural sector in Sri Lanka, which is overwhelmingly dominated by the traditional agriculture.

The domestic agriculture, the largest informal sector of the economy, contributes immensely to the livelihood of the rural population. Other traditional activities such as livestock keeping and the rural cottage industries are directly related to this sector. Some other non-traditional activities in the rural sector, namely small groceries, bakers, cycle repairing shops, depend on the performance of the domestic agriculture. Employees in the domestic agricultural sector have seasonal work most of the time. There are no formal working hours, and public holidays. No proper social security schemes are available to look after them at old age except for the existing farmers' pension schemes. This is a serious issue in the informal sector, particularly in nonfarming self-employment sector, which accounted for $32.2 \%$ of total employment in 2013.

Plantation sector, consisting of tea, rubber, and coconut, is also part of the agriculture. It used to offer the highest level of regular employment, and in 1953 it contributed $29 \%$ of the total employment of the country. In 1996 this has gone down to $20 \%$. Similarly, the share of the plantation sector in GDP in the late 1940s, which had been estimated at $37 \%$, declined to $4 \%$ in 1996 , and it contributed $3.4 \%$ to GDP in 2010.

The informal sector has been part and parcel of the plantation agriculture since it was introduced to the country. Petty traders and some other services came to the estate sector under the prevalent system. Most of the laborers worked for the plantations without the security of labor rules and regulations.

The major policy shift was witnessed by the land reforms in 1972 and 1975, which made two types of effects on the plantation sector. On the one hand, some informal activities were formalised under the state ownership, and on the other hand, the land 
redistribution among the landless people further expanded the domestic sector's informal activities.

\section{Labor force and the informal sector}

Sri Lanka inherited 7.1 million people at her political independence in 1948, and this reached 20.5 million in 2013. It is estimated that during both the inter census periods of 1946-1953 and 1953-1963 the rate of increase in the labor force was less than that of the rate of growth in the population. However, during 1963-1971 the situation reversed, resulting in an average growth of $3.3 \%$ per year in the labor force as against a 2.2 growth of population. The labor force growth increased sharply in the early 1980 s and declined to $1.7 \%$ annual growth rate in 2008-2013.

The labor market in Sri Lanka is broadly divided into two: organized and unorganized sectors. Employment covered by the labor market such as government, semi government, cooperative, and organized private sectors belong to the first category while unorganized enterprises not covered by the labor market regulations belong to the second category, namely the unorganized sector. According to the most recent available data as of 2006, regarding the different status of employment, $47 \%$ of the total informal sector employment are own-account workers while $91 \%$ of formal sector employment are regular employees.

Unemployment that was low in the 1950s became a serious problem in the $1970 \mathrm{~s}$. It is still high, especially among young first-time job seekers. Sri Lanka is one of the most densely populated countries in the world, though the distribution is not equal. The country was able to avoid a large-scale migration of people from rural to urban centers; the share of urban population to total population increased from $15 \%$ in 1946 to $18.3 \%$ in 2013. 


\section{Table 2}

Labor force and employment: SAARC countries

\begin{tabular}{|c|c|c|c|c|c|c|c|c|c|c|}
\hline & 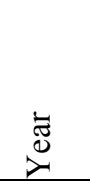 & & 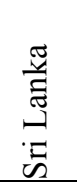 & 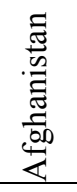 & 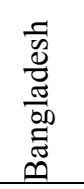 & 壱 & $\underset{\Xi}{\overparen{\Xi}}$ & $\frac{e^{\infty}}{\sum^{\pi}}$ & $\begin{array}{l}\bar{\pi} \\
\tilde{0} \\
z\end{array}$ & 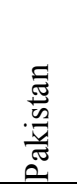 \\
\hline \multirow{2}{*}{$\begin{array}{l}\text { Labor force } \\
\text { participation } \\
\text { rate }\end{array}$} & \multirow[t]{2}{*}{2011} & Male & 74.0 & 80.3 & 84.3 & 76.5 & 80.7 & 76.8 & 87.6 & 83.2 \\
\hline & & Female & 34.4 & 15.7 & 57.2 & 65.8 & 29.0 & 55.7 & 80.4 & 22.7 \\
\hline $\begin{array}{l}\text { Unemployment } \\
\text { rate }\end{array}$ & 2012 & $\%$ & 4.0 & - & 4.5 & 2.1 & 2.7 & 11.7 & 2.7 & 5.9 \\
\hline \multirow{3}{*}{$\begin{array}{l}\text { Employment } \\
\text { (\% of total } \\
\text { employment }\end{array}$} & \multirow[t]{3}{*}{2012} & Agriculture & 31.0 & - & 47.5 & 62.2 & 48.9 & 4.3 & - & 54.1 \\
\hline & & Industry & 26.1 & - & 12.6 & 8.6 & 24.3 & 9.4 & - & 13.7 \\
\hline & & Services & 42.9 & - & 39.9 & 29.1 & 26.8 & 86.3 & - & 41.2 \\
\hline
\end{tabular}

Source: Central Bank of Sri Lanka, 2014

One of the salient features of poverty is the incidence of child labor, which is again almost confined to the informal sector in all three sub-sectors of the economy including rural, urban, and estate ones. The ILO estimated that there were between 250,000 and 500,000 child laborers in Sri Lanka in 2006. The most common forms of child labor are domestic employment (i.e. as household servants), involuntary begging on the streets, and child prostitution, working in the informal sector, in the gemstones industry, and in sectors such as tourism and fishing.

At certain points the organized and unorganized sectors are overlapping, to wit: organized private sector hires temporary laborers, and public sector rents out certain services and sub contract to the unorganized sectors in the economy.

The labor supplies in the informal sector show the coping behaviour of individuals and families in an economic environment where earning opportunities are scarce. This is an obvious fact in land scarce areas as well as in hostile climatic areas.

Women's share of informal sector employment has remained high in all three major sectors - rural, urban, and estate - in the country. They comprise most of the unpaid family helpers and home-based workers. Their wages are, however, relatively low (Table 3). 


\section{Table 3}

Informal sector daily wages by sector and gender

\begin{tabular}{lllll}
\hline Sector & 2005 & 2006 & 2007 & 2012 \\
\hline Tea & & & & \\
Male & 300 & 333 & 378 & 691 \\
Female & 217 & 234 & 261 & 512 \\
Rubber & & & & \\
Male & 305 & 335 & 384 & 741 \\
Female & 230 & 249 & 279 & 585 \\
Paddy & & & & \\
Male & 361 & 391 & 453 & 787 \\
Female & 261 & 293 & 331 & 599 \\
\hline
\end{tabular}

Source: Central Bank of Sri Lanka, various issues

Sri Lanka has a large working population in the informal sector. They are mainly concentrated in the transport, fisheries, education, and construction sectors and also include migrant workers, self-employment, and domestic employees' categories of employment. Unfortunately, although this constitutes a large segment of the working population in Sri Lanka, there is little or no protection at all for these workers. This is mainly due to the fact that legal protection for workers in Sri Lanka depends on the existence of a contract of employment. Most of these workers do not have contracts of employment because the very nature of their employment does not envisage such a legal obligation. The informal sector in Sri Lanka is not organized as a collective force has given rise to a serious lack of awareness in relation to the benefits that they may have. Another drawback that workers in the informal sector face in Sri Lanka is that there is very little opportunity for skills development. Also, the fact that traditionally trade unions in Sri Lanka have concentrated mainly on the rights of workers in the formal sector has also contributed to this situation. The difficulty in obtaining trade union dues from workers in the informal sector is a reason for the traditional unions not to venture into the informal sector workers. 


\section{Conclusions}

The informal sector, on the one hand, is an unorganized nuisance, and its members, in many instances, do not follow many rules and regulations. On the other hand, it provides jobs for very vulnerable low-income groups in rural and urban sectors while contributing to the GDP immensely in developing countries though its contribution is not counted in measuring GDP. Obviously, production, exchange, and consumption in this sector are largely unrecognized, unrecorded, and unregulated. Informal sector plays an important role in the Sri Lanka's economy even if the dividing line between formal and informal sectors is not clear and direct forward. It is visible most, if not all, of the time, that the two sectors overlap as well as depend on each other. It is also timely and important that the linkages between the formal and informal sectors should be promoted through an appropriate inclusive policy and regulatory environment.

The domestic (traditional) agriculture and related activities in Sri Lanka are dominated by the informal sector, which in turn is further strengthened by such underworld activities as drug trafficking, prostitution, contract crimes, etc. Similarly, fear of tax burden, bribes, bureaucratic bungling, archaic rules and regulations, and lack of dividends in formal activities drive many people from the formal sector to the informal one.

As can be seen, the informal sector provides jobs and reduces unemployment and underemployment; in many cases, however, the jobs are low paying, and job security is poor. It bolsters entrepreneurial activities, but at the detriment of state regulations' compliance, particularly regarding tax and labor regulations. According to Gunatilake (2008, pp. iv)

"Policy needs to concentrate on ensuring decent work standards in informal jobs, particularly on implementing measures that improve productivity and incomes, enforce regulations relating to occupational safety and health, and strengthen social insurance, assistance, and welfare schemes."

In spite of this, irregularity of the informal sector in Sri Lankan economy creates not just economic problems, but also many social issues. With the strong and uncontrolled informal economic activities economic policies may not work in the proper direction. Conventional macroeconomic policies become powerless to some extent in this process. Without incorporating the contribution of the informal sector, macroeconomic data cannot give a vivid picture about the economy. It is timely and 
imperative to conduct a field survey to study the true nature of the informal sector and its real contribution to national and international economies

\section{Notes}

${ }^{1}$ Although the concept of "informal sector" came in to the development scene in 1972, its roots reach back to the economic development efforts of the 1950s and 1960s.

2 Economic Progress of Independent Sri Lanka 1948-1998, Central Bank of Sri Lanka, p.84

${ }^{3}$ Economic Progress of Independent Sri Lanka 1948-1998, Central Bank of Sri Lanka, p.48.

${ }^{4}$ http://www.adb.org/Documents/CAPs/SRI/0102.asp

\section{References}

Athukorala, P. (1986). The impact of 1977 policy reforms on domestic industry. Upanathi: The Journal of Sri Lanka Association of Economists, 1(1), 69-106.

Central Bank of Sri Lanka. (1991). Growth and social progress in Sri Lanka. Colombo, Sri Lanka: Central Bank of Sri Lanka.

Central Bank of Sri Lanka. (1998). Economic progress of independent Sri Lanka 1948-1998. Colombo, Sri Lanka: Central Bank of Sri Lanka.

Central Bank of Sri Lanka. (2003). Annual report. Colombo, Sri Lanka: Central Bank of Sri Lanka, pp. 14-21.

Central Bank of Sri Lanka. (2014). Sri Lanka socio-economic data 2014. Colombo, Sri Lanka: Central Bank of Sri Lanka.

Dayaratna-Banda, O. G. (2007). Informal trade in Sri Lanka. A paper prepared for the project on Legal Empowerment of the Poor, Pathfinder Foundation, Colombo, Sri Lanka.

Department of Census and Statistics. (1983). Survey of manufacturing industries. Colombo, Sri Lanka: Ministry of Finance and Planning.

Department of Census and Statistics. (2009). Poverty in Sri Lanka. Colombo, Sri Lanka: Ministry of Finance and Planning.

de Silva, S. (2013). The dilemma of the informal economy. Rajagiriya, Sri Lanka: Employers Federation of Ceylon.

Ghafur, A., Moinul Islam, M., \& Faiz, N. (1990). Illegal international trade in Bangladesh: Impact on the domestic economy (phase I). Dhaka, Bangladesh: Bangladesh Institute of Development Studies.

Gunatilake, R. (2008). Informal employment in Sri Lanka: Nature, probability of employment, and determinants of wages. New Delhi, India: International Labor Organization. 
Hettige, S. T. (1986). Employment in the urban informal sector in Sri Lanka. Paper presented at Policy Studies Conference II, Colombo, Sri Lanka.

Hettige, S. T. (1989). Urban informal economy, the politico-economic process, and the sharing of urban space: Recent trends with particular reference to Colombo. Upanathi: The Journal of Sri Lanka Association of Economists, 4(1\&2).

Hettige, S. T. (1990). The urban informal sector and the politico-economic process: Recent trends with particular reference to Colombo. Upanathi: The Journal of Sri Lanka Association of Economists, 4(1\&2).

ILO/ARTEP. (1986). The impact of economic liberalization on the small-scale and rural industries of Sri Lanka. New Delhi, India.

ILO. (2002). Unprotected labor: What role for unions in the informal economy. Labor Education, 2002/2, No. 127.

Karmacharya, B. K. (2002). Informal trade in the SAARC region: Nepal's informal trade with India. Kathmandu, Nepal: Nepal Council for Development Research.

Karunatilaka, H. N. S. (1981). The economy of Sri Lanka. Colombo, Sri Lanka: Center for Demographic and Socio-Economic Studies.

Marga Institute. (1979). The informal sector of Colombo City. Colombo, Sri Lanka: Marga Institute.

Marga Institute. (1992). Study of education-employment linkages. World Bank/IDA funded General Education Project, Sri Lanka.

Papola, T. S. (1980). Informal sector: Concept and Policy. Economic and Political Weekly, XV(18), 817-824.

Sanderatne, N. (1989). The informal economy: Issues and perspectives. Upanathi: The Journal of Sri Lanka Association of Economists, 3(5), 23-56.

Sanderatne, N. (1991). The informal sector in Sri Lanka: Dynamism and resilience. In A. L. Chickering \& M. Salahdine (eds.), The silent revolution: The informal sector in five Asian and near Eastern countries. San Francisco, Calif: ICS Press.

Sanderatne, N. (2002). The informal sector in Sri Lanka: Its nature and extent and the impact of globalization. Genève, Switzerland: International Labor Organization.

Senakaarachchi, R. B. (1985). Non-Farm employment in the rural sector in Sri Lanka (Seminar Paper No. 4/85). Colombo, Sri Lanka: Association of Economists (mimeo).

Swaminathan, M. (1991). Understanding the "Informal Sector": A survey (WIDER Working Papers). Centre for International Studies, M. I. T Cambridge, Massachusetts 02139.

Taneja, N., Sarvananthan, M., Karmacharya, B., \& Pohit, S. (2002). Informal trade in the SAARC region: A case study of India, Sri Lanka, and Nepal. Retrieved from http://www.researchgate.net/publication/266098369 
The World Bank Group. (1978). Sri Lanka: Plans and policies for industrial development. Washington, DC: The World Bank Group.

Vodopivec, M., \& Arunatilake, N. (2008). The impact of population aging and the labor market: The case of Sri Lanka (IZA Discussion Paper No. 3456). Bonn, Germany: Institute for the Study of Labor. 